\title{
Assessment of the Refuse Collection Charges in Covering Waste Management Cost: The Case of ILALA Municipality -Dar Es Salaam, Tanzania
}

\author{
TP. Dr. Hussein M. Omar, Registered Town Planner and Environmental Officer, \\ Vice President Office-Division of Environment (United Republic of Tanzania), \\ P.O .Box 2502, Dodoma, Tanzania.
}

\begin{abstract}
The world urban population is expected to increase by 72 per cent by 2050, to reach nearly 6 billion in 2050 from 3 billion in 2011 (UN, 2012, Hussein 2019). By mid-century the world urban population will likely be the same size as the world's total population was in 2002 (UN, 2011, and Hussein, 2018). Although the global average in 2014 reached 54 per cent, the percentages are already around $80 \%$ in the Americas, and over $70 \%$ in Europe and Oceania, but only $48 \%$ in Asia and 40\% in Africa (UN, 2014, Hussein, 2019).
\end{abstract}

\section{INTRODUCTION}

In Tanzania statistical trend indicates that proportion of the population living in urban areas is ever-increasing. According to URT, 2002 in Bakanga 2014, the urbanisation rate increased from 5\% in 1967 to $13 \%$ in 1978 and from $21 \%$ in 1988 to $27 \%$ in 2002. In the country, Dar es Salaam is the largest City, which has doubled its population to 3.3 million inhabitants in 20 years (UN-Habitat, 2008, Hussein, 2019). The City has reached 4.6 million populations in 2012 (URT, 2012). Currently, the City is estimated to have reached 5.3 million populations (URT, 2018)

Rapid urbanization in developing countries including Tanzania has increased pressure on urban infrastructure and henceforth resulting into poor urban service delivery including waste collection services (Hussein, 2018). Several scholars including Kironde 1999; Majani 2002; Kyessi, 2002 and Tibaijuka, 2007 and Babyebonela 2013 have highlighted that adequate resource as pre-requisite for effective solid waste management.

In Tanzania Refuse Collection Charges (RCCs) have been used by most Local Government Authorities as source of finance for covering waste management cost. In 2019, Moshi, Iringa, and Arusha, Local Government Authorities (LGAs) were named as the first, the second and the third cleanest LGAs in the country respectively. However, the RCCs bases for the three LGAs are far less compared to the RCCs base for LGAs in Dar es Salaam, City including Ilala, Municipality. Therefore, despite the presence of other factors that might affect efficiency in waste management services, it is the interest of this study to assess the efficiency in the collection of Refuse Collection Charges in meeting waste management cost in Ilala Municipality.

\section{OBJECTIVE}

The study aimed at assessing RCCs collection efficiency in covering solid waste management Cost in Ilala Municipality.

Specific Objectives
To analyse waste management database for Ilala
Municipality
To analyses the challenges for effective RCCs
collection in Ilala Municipality
To recommend on the best practice

\section{LITERATURE REVIEW}

\section{A. Theories and Concepts \\ $>$ Governance Concept}

According to Landell-Mills and Serageldin (1991, p. 14) Governance defined as the use of political power to manage a nation's affairs. . . . It encompasses the state's institutional and structural arrangements, decision-making processes, and implementation capacity, and the relationship between government officials and the public. In another development Chazan, 1992:122 defined Governance as the capacity to establish and sustain workable relations between individual actors in order to promote collective goals (Chazan, 1992:122). It was further defined by Galadima (1998:117) as; a process of organizing and managing legitimate power structures, entrusted by the people, to provide law and order, protect fundamental human rights, ensure rule of law and due process of law, provide for the basic needs and welfare of the people and the pursuit of their happiness.

Management of Refuse Collection Charges involves several stakeholders and various processes. The involved processes include establishment of the inventory of the service recipients; identification, recruitment and management of the personnel for the collection of RCCs; Establishment of the RCCs collection systems; Management of the collected RCCs, and Development of accountability and enforcement mechanisms systems. 
The effectiveness of each process depends on the effectiveness of the roles played by each stakeholder. The key role of the Government to establish and sustain workable relations among actors is very vital in enhancing effective RCCs management. Based on that this paper uses Chazan, (1992) and Galadima (1998:117) concepts of governance which emphasize on the capacity of the Government to establish and sustain workable relations between individual actors in order to promote collective goals and provision of basic needs and welfare of the people respectively.

\section{Organization theory}

According to Meyer, (2008), Organisations can be described as "structures of recognized and accepted roles". Further, Max Weber, added that an organization must adhere to specified set of rules and hierarchy of officials placed within the organization based on their skill and expertise in performing particular roles (Stenlås, 1999).

Moreover, Kyessi (2002:66) in Kalwani (2009) and Hussein (2018) has included Technology as among the components in resource mobilization such as RCCs collection. The theory will be used to guide in the assessment of the distribution of roles and responsibility in the RCCs.

\section{Conceptualizing resource enhancement for effective waste collection services}

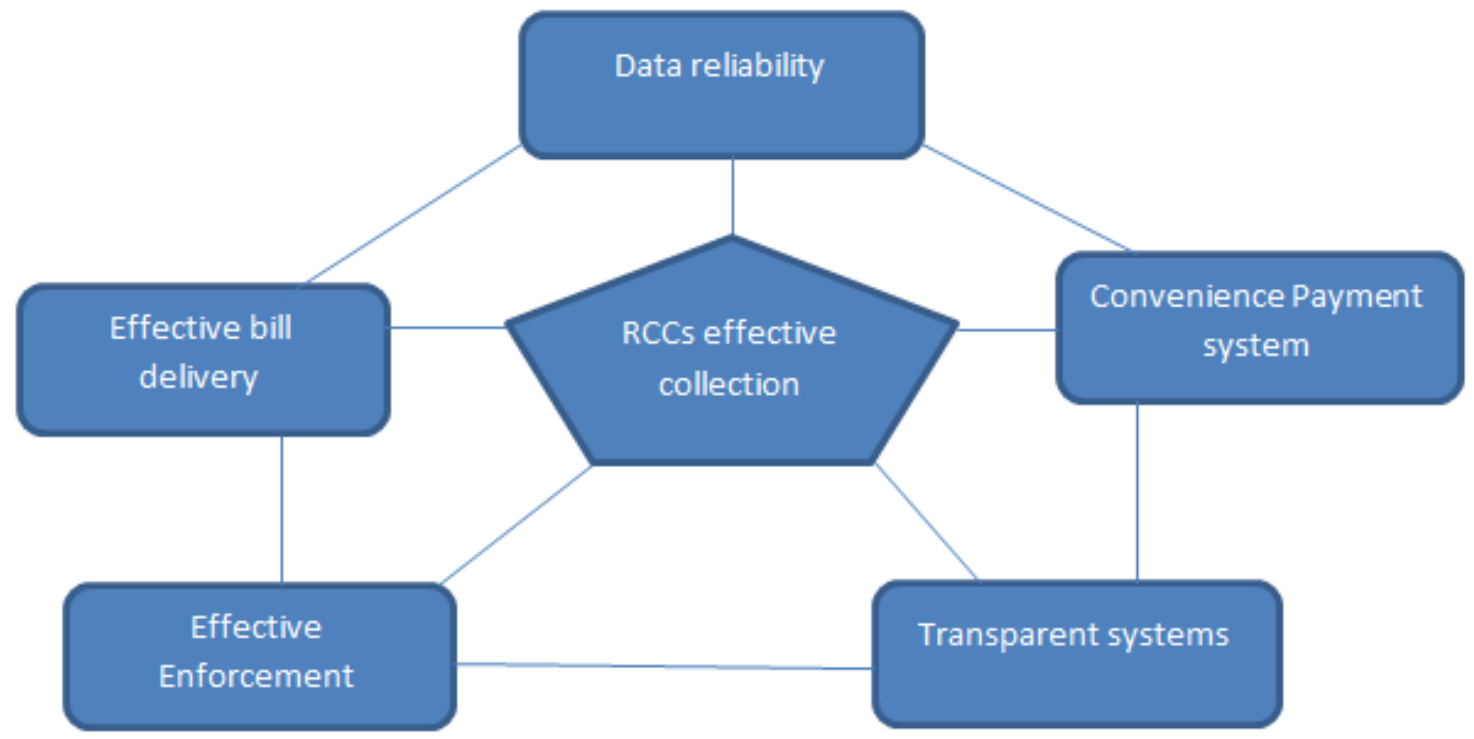

Fig 1

Source: Own construct,( 2020)

\section{- Data reliability}

Effective RCCs collection requires full understanding on the potential number of the customers that are expected to pay for the rendered services. Reliable data guarantee realistic budget estimation in the planning for waste management service especially during tendering processes where waste collection services privatized under Public Private Partnership approach. The required data may include the amount of waste generated, the expected amount of waste to be collected, the expected operational costs, the scope of service coverage, and the expected revenue to be collected. Also, reliable data will be very useful in the enforcement process and consequently, guarantee efficiency in the collection of RCCs.

\section{- Effective Bill Delivery}

Billing processes play a critical role in revenue for a number of public sector organisations including municipalities (Rao, 2012). In the delivery of public services, including waste management services billing drives cash flow and is the key source of information for customers using these services (ibid). In many countries, reforming billing processes, coupled with strengthening collection processes, has improved revenue collection.

\section{- Convenient Payment system}

Convenience in the payment of bills for a rendered service is vital for effective revenue collection. The payment process has to be simple and accessible. Long queue or complicated process may discourage the willingness of the services recipients to pay for the offered service. Adoption of user friendly technology such as mobile payments plays a greater role in motivating customers to pay for the offered services.

\section{- Transparency systems}

Effective management of the collected RCCs requires transparency systems that enable the tracking of a very single cent that collected. Such systems are also essentials in enhancing the accountability and promoting the culture of compliance. The technology that enhances transparency can be used in the area registration of service recipients, bill delivery and payment. 


\section{- Effective Enforcement}

Enforcement is one of the vital areas in the collection of revenues including RCCs. It is almost very common to that have defaulters in the revenue collection. However, the extent at which the enforcement is carried out is very vital in encouraging people to pay for the services.

\section{METHODOLOGY}

The methodology involves a purposeful selection of $12(100 \%)$ formal waste collection service providers in the Municipality and 10 Ward Executive Officers at the Central Business District and 5 Municipal officials from waste Management department and Finance department. The selected service providers were GREEN WASTEPRO, TIRIMA, and SATEK; PICK TRADING, KMUJ, GIN TRADERS, MANDELA GROUP, WAJANE STAKISHARI MAZINGIRA, MWANGAZA VICOBA MAZINGIRA, MAVONDA COMPANY LTD, MAJOHE GROUP, KIMWEDE and KAJENJELE. The data collection was conducted from $1^{\text {st }}$ April to $15^{\text {th }}$ June 2020. The study focuses on the current practice of refuse collection charges and the subsequent challenges. The data collection included: solid waste generated and collected from household, commercial areas and institutions; solid waste recycling and re-use practices; solid waste disposal systems; and refuse collection charges systems and challenges. Primary data were collected from the waste collection service providers; municipal officials; and informal service providers. The direct observation was also applied in primary data collection. The secondary data was collected through review of various documents both electronic and hard copies. Some of the reviews documents include; Dar es Salaam Master Plan 2016-2036; Dar es Salaam City Profile; The National Environmental Policy of 1997; The Environmental Management Act of 2004; The Local Government (Urban Authorities) Act No. 8 of 1982,
The Environment Management (Solid Waste Regulations of 2009), Public Procurement Act (PPA), 2011 (amended 2016); and Public Procurement Act Regulations of 2013 (Amended in 2016) and Local Government By-laws. Also, various published papers and thesis on waste management were reviewed.

\section{RESULTS AND DISCUSSION}

\section{> Lack of Reliable Waste Management Data}

Solid waste management data include waste generation, collection, recycling and re-use, and solid waste and management disposal.

\section{- Lack of reliable waste generation data}

In Ilala Municipality it was found that there is no reliable waste statistics and waste characterization studies to define the quantity and quality of waste generated. The available waste management data was established by JICA in 2013. Since then the amount of waste generated per day claimed by the Municipal council to be 1100 tones. However, that did not consider the population growth witnessed in the Municipality between 2013 and 2020. Moreover, according to JICA (2013) $0.80 \mathrm{~kg}$ was the per capita waste generation in the municipality. This implies that from the estimated $1,580,000$ population the municipality currently is generating 1264 tons per day.

Again, The Dar es Salaam Master Plan (2016-2036) indicated that $1 \mathrm{~kg}$ as per capita waste generation in Dar es Salaam including Ilala Municipality. This implies that the Municipality currently generates 1581 tons per day. Table 1.1 shows the distribution of the amount of waste generated by type based on the data from Ilala Municipal Council office, JICA study and Dar es salaam Master Plan (20162036). Table 1 shows the quantity distribution of generated waste by source.

\begin{tabular}{|c|c|c|c|c|c|}
\hline S/NO & Type of waste & $\begin{array}{c}\text { Amount generated } \\
\text { per day based on } \\
\text { Municipal Data }\end{array}$ & $\begin{array}{c}\text { Amount of waste } \\
\text { generated based on } \\
\mathbf{0 . 8 K g / C a p i t a} \text { (JICA, } \\
\mathbf{2 0 1 3}\end{array}$ & $\begin{array}{c}\text { Amount of waste generated } \\
\text { based on 1Kg per Capita } \\
\text { (DSM master 2016-2036) }\end{array}$ & $\begin{array}{c}\text { Percentage } \\
\text { (DSM }\end{array}$ \\
\hline 1. & Household & 725 & 832.97 & 1041.22 & 65.90 \\
\hline 2. & Commercial & 190.0 & 218.29 & 272.86 & 17.27 \\
\hline 3. & Institutional & 9.0 & 10.23 & 12.79 & 0.81 \\
\hline 4. & Markets & 90.0 & 103.30 & 129.24 & 8.18 \\
\hline 6. & Informal sector & 86.0 & 98.71 & 123.39 & 7.81 \\
\hline & TOTAL & $\mathbf{1 1 0 0}$ & $\mathbf{1 2 6 4}$ & $\mathbf{1 5 8 0}$ & \\
\hline
\end{tabular}

Table 1:- Sources of Solid Waste per Day in Ilala Municipality.

Source: Field Work, 2020

\section{- Lack of reliable waste collection data}

In interview with Ilala Municipal Waste management officers, it was highlighted that 33 per cent of the generated waste per day is collected. However, the data collected from service providers have shown that 46 per cent of the generated waste collected per day. This section discusses the waste collection by Municipal council, Formal and informal service providers.

\section{$\checkmark$ Waste collection services by Municipal Council}

The Ilala Municipal Council provides waste collection services in Public places. There are about 12 public places that enjoy the service from the Council. The places include: State house; Vice President Office; The Office of the President of Zanzibar; Prime Minister's Office; Diamond, Olympio, Maktaba, Upanga, Mnazi Mmoja, and Lumumba Primary Schools; Mnazi mmoja, Vingunguti and Buguruni Health Centres; IDC Clininc; and Public Open Spaces such as Ocean road Beach, Mnazi Mmoja Park and Major roads 
at the outskirt of the Municipality. Also the council provides waste collection services in major markets in the Municipality. Among the Markets enjoying waste collection services from the council include; Kariakoo, Buguruni, Ilala, Kisutu, Tabata, Kigogo Sambusa and Feri Markets. The Council managed to collect a total of 106.2 tons per day. This is equivalent to only 9.76, 8.4, and 6.7 per cent of the generated waste in the Municipality per day based on municipal council data, $0.80 \mathrm{~kg}$ per capita waste generation and $1 \mathrm{~kg}$ per capita waste generation respectively. Based on the Dar es Salam Master Plan (2016-2036) estimates the market waste constitutes 3.31 per cent of the total collected waste by the Council. Table 3 shows the distribution of the amount of waste collected from several markets in the Municipality.

\begin{tabular}{|c|c|c|}
\hline S/no. & Market & Amount of waste collected per week (tons) \\
\hline 1. & Buguruni & 205 \\
\hline 2. & Ilala & 67 \\
\hline 3. & Kisutu, Kigogo Sambusa and Tabata & 28 \\
\hline 4. & Feri & 31 \\
\hline 5. & Kariakoo & 35 \\
\hline & Total & $\mathbf{3 6 6}$ \\
\hline
\end{tabular}

Table 2:- Quantity of Waste Collected by Market

Source: Ilala Municipal Council

\section{$\checkmark$ Waste Collection by Formal Service Providers}

The Municipality has a total of 12 formal waste collection service providers providing the services in 28 out of 36 Wards. Among the 12 formal service providers only 8 are recognized by Municipal council. The remaining 4 service providers are recognized by sub-ward leaders and provide services with negotiation with sub-ward leaders. However, the service providers who are recognized by the council obtained through a competitive tendering process. Despite of being working for the council, it was observed that there is no any system in the Municipality to enable the Council to collect the data of the collected waste on daily basis. Consequently, the data of the collected waste per day reported at the Municipal council differs with data obtained from service providers. The council reports waste collection rate of 33 per cent per day while the data obtained from the waste collection companies showed 46 per cent of the generated waste collected every day.

Table 3 shows the amount of waste collected by formal service providers by Wards and the number of households serviced.

\begin{tabular}{|c|c|c|c|c|}
\hline S/no. & Name of Service Providers & Areas serviced (Wards) & No. HHs Served & $\begin{array}{c}\text { Amount of waste collected } \\
\text { (tons/day) }\end{array}$ \\
\hline 1. & Green Waste Pro & $\begin{array}{c}\text { Kivukoni } \\
\text { Kisutu } \\
\text { Mchafukoge } \\
\text { Gongo la mboto }\end{array}$ & $\begin{array}{c}6800 \\
2492 \\
10688 \\
9098 \\
\end{array}$ & $\begin{array}{c}150 \\
- \\
- \\
3.5 \\
\end{array}$ \\
\hline 2. & SATEKI Trading Co. Ltd & $\begin{array}{l}\text { Ilala and } \\
\text { Ukonga }\end{array}$ & $\begin{array}{c}7228 \\
11954 \\
\end{array}$ & $\begin{array}{c}92 \\
126 \\
\end{array}$ \\
\hline 3. & Kajenjele Co. Ltd & $\begin{array}{l}\text { Mchikichini } \\
\text { Kariakoo, } \\
\text { Buguruni } \\
\text { Mnyamani }\end{array}$ & $\begin{array}{c}6617 \\
12000 \\
12000 \\
8338\end{array}$ & $\begin{array}{c}40 \\
60 \\
8 \\
7\end{array}$ \\
\hline & GIN Investment Ltd & Jangwani & 4190 & 18.42 \\
\hline & & Kiwalani & 1000 & 10.42 \\
\hline 4. & Pick Trading & Gerezani & 1589 & 30 \\
\hline 5. & TIRIMA Enterprises & $\begin{array}{l}\text { Upanga Mashariki, } \\
\text { Upanga Magharibi }\end{array}$ & $\begin{array}{l}3577 \\
3394\end{array}$ & 18 \\
\hline 6. & $\begin{array}{l}\text { MANDELA Cleaners } \\
\text { Group }\end{array}$ & $\begin{array}{c}\text { Kinyerezi } \\
\text { Bonyokwa } \\
\end{array}$ & $\begin{array}{l}500 \\
700 \\
\end{array}$ & 9 \\
\hline 7. & K.M.U.J & Vingunguti Ward & 5694 & 15 \\
\hline 8. & KIMWEDE & $\begin{array}{l}\text { Tabata Ward } \\
\text { Liwiti Ward } \\
\text { Kimanga Ward }\end{array}$ & $\begin{array}{c}9238 \\
6780 \\
780 \\
\end{array}$ & $\begin{array}{c}40 \\
- \\
-\end{array}$ \\
\hline 9. & MAJOHE GROUP & Majohe Ward & 2900 & 16 \\
\hline 10. & $\begin{array}{l}\text { MAVONDA COMPANY } \\
\text { LTD }\end{array}$ & Segerea Ward & 2158 & 60 \\
\hline \multirow[t]{3}{*}{11.} & \multirow{3}{*}{$\begin{array}{c}\text { MWANGAZA VICOBA } \\
\text { MAZINGIRA }\end{array}$} & Pugu Stesheni & 1600 & - \\
\hline & & Pugu Wards & 2000 & - \\
\hline & & Chanika Wards & 1200 & - \\
\hline
\end{tabular}


ISSN No:-2456-2165

\begin{tabular}{|c|c|c|c|c|}
\hline & & Zingiziwa Ward & 6400 & 10 \\
\hline 12. & $\begin{array}{c}\text { WAJANE STAKISHARI } \\
\text { MAZINGIRA }\end{array}$ & Kipawa & 1050 & 10 \\
\hline & \multicolumn{2}{|c|}{ Total } & $\mathbf{1 4 1 , 9 6 5}$ & $\mathbf{7 2 3 . 3 4}$ \\
\hline
\end{tabular}

Table 3:- Service Coverage Formal Service Providers in the Municipality.

\section{$\checkmark$ Waste collection by Informal service providers}

The council has also, lack reliable data on the amount of waste collected by informal service providers. However, based on per capita waste generation 54 per cent of the generated waste is managed informally. This may include informal collection, burying or open burning. For example, in Vingunguti Ward 50 percent of the Ward was served by Informal service providers. The sub-wards (Mitaa) served by informal service providers include; Mtakuja, Majengo, and Kombo. A total of 8304 households are served my informal service providers in the Ward. The number of households served by informal service providers by sub-wards is 1823, 1773, and 4708 for Mtakuja, Majengo and Kombo sub-wards respectively. The formal service provider (K.M.U.J) serves only 5694 households. This implies that a greater number of residents in Vingunguti were served by informal service providers. This was also, observed in Gongo la Mboto where Green waste Company serve only 50 per cent of the sub-wards. The served sub-wards by Green wastePro are Gongo la mboto and Guluka kwalala. The remaining 50 per cent served by informal service providers. The sub-wards served by informal service providers are Ulingoni A and Ulingoni B. Also, 65 per cent of the households in Tabata Ward obtained waste collection services from informal service providers.

Table 4 shows the detail coverage of informal service providers by Wards in the Municipality

\begin{tabular}{|c|c|c|c|c|}
\hline S/No. & Ward & No. of HHs served per Wards & Total Population served & $\begin{array}{c}\text { Estimated collection } \\
\text { (tons/day) based on } 1 \mathrm{~kg} \text { per } \\
\text { capita waste generation }\end{array}$ \\
\hline 1. & Gongo la Mboto & 4565 & 23,478 & 23.47 \\
\hline 3. & Mnyamani & 2432 & 9728 & 9.72 \\
\hline 4. & Kinyerezi & 6937 & 51,375 & 51.3 \\
\hline 7. & Tabata & 14,365 & 57460 & 57.46 \\
\hline 8. & Majohe & 15143 & 99503 & 99.50 \\
\hline 9. & Segerea & 6,416 & 32,300 & 32.30 \\
\hline 10. & Pugu station & 3581 & 16823 & 16.83 \\
\hline 11. & Pugu & 22729 & 44034 & 44.03 \\
\hline 16. & Kisukuru & 6136 & 32071 & 32.07 \\
\hline 17. & Kipawa, & 19817 & 55764 & 55.74 \\
\hline 18. & Minazi Mirefu, & 9895 & 39572 & 39.57 \\
\hline 19. & Msongola, & 10418 & 30422 & 30.42 \\
\hline 20. & Buyuni, & 9295 & 39813 & 39.81 \\
\hline 21. & Kitunda & 10367 & 42167 & 42.12 \\
\hline \multirow[t]{2}{*}{22.} & Mzinga & 15813 & 63248 & 63.25 \\
\hline & Total & 212019 & $\mathbf{8 5 8 2 7 7}$ & 858.1 \\
\hline
\end{tabular}

Table 4:- Waste collection service coverage by informal service providers

Source: Field Survey (2020)

From Table 3 and 4 it become clear that much of the waste in the municipality is managed informally. Figure 2 shows the spatial service coverage by formal and informal systems in the municipality. 


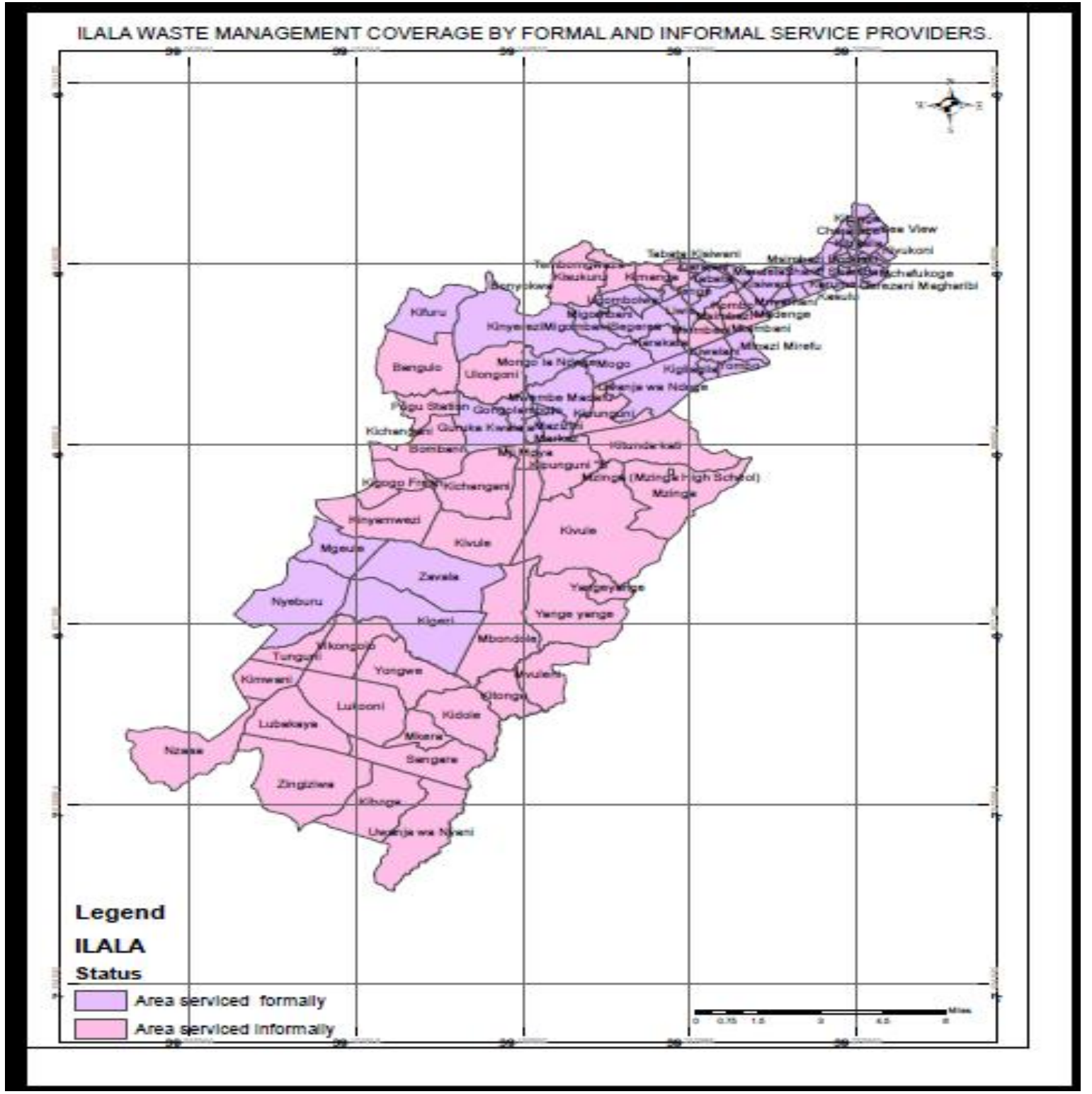

Fig 2:- Spatial coverage of waste collection services by Formal and Informal service providers in Ilala Municipality

- Lack of reliable data on solid waste recycling and re-use

In the Municipality there is no organized system for tracking the amount of recyclable waste collected. The practice shows that recyclable waste is informally collected and sold to the waste collection agents who spread all over the Municipality. The waste collection agents sell the recyclable waste to the recycling industries. However, only few organized formal companies involved in waste recycling have statistics on the amount of recyclable waste collected.

For example, Green WastePro Company found to collects 1.5 tons of recyclable waste per day of which Plastic (0.8tons), Cardboard ( 0.6 tons) and Nylon ( 0.1 tons). The Zaid Recyclers which involved in the recycling of card board and papers found to collect 0.852 tons of cardboards per day. Figure 3 shows the waste pickers brought the cardboards at Zaid Recyclers yard. 


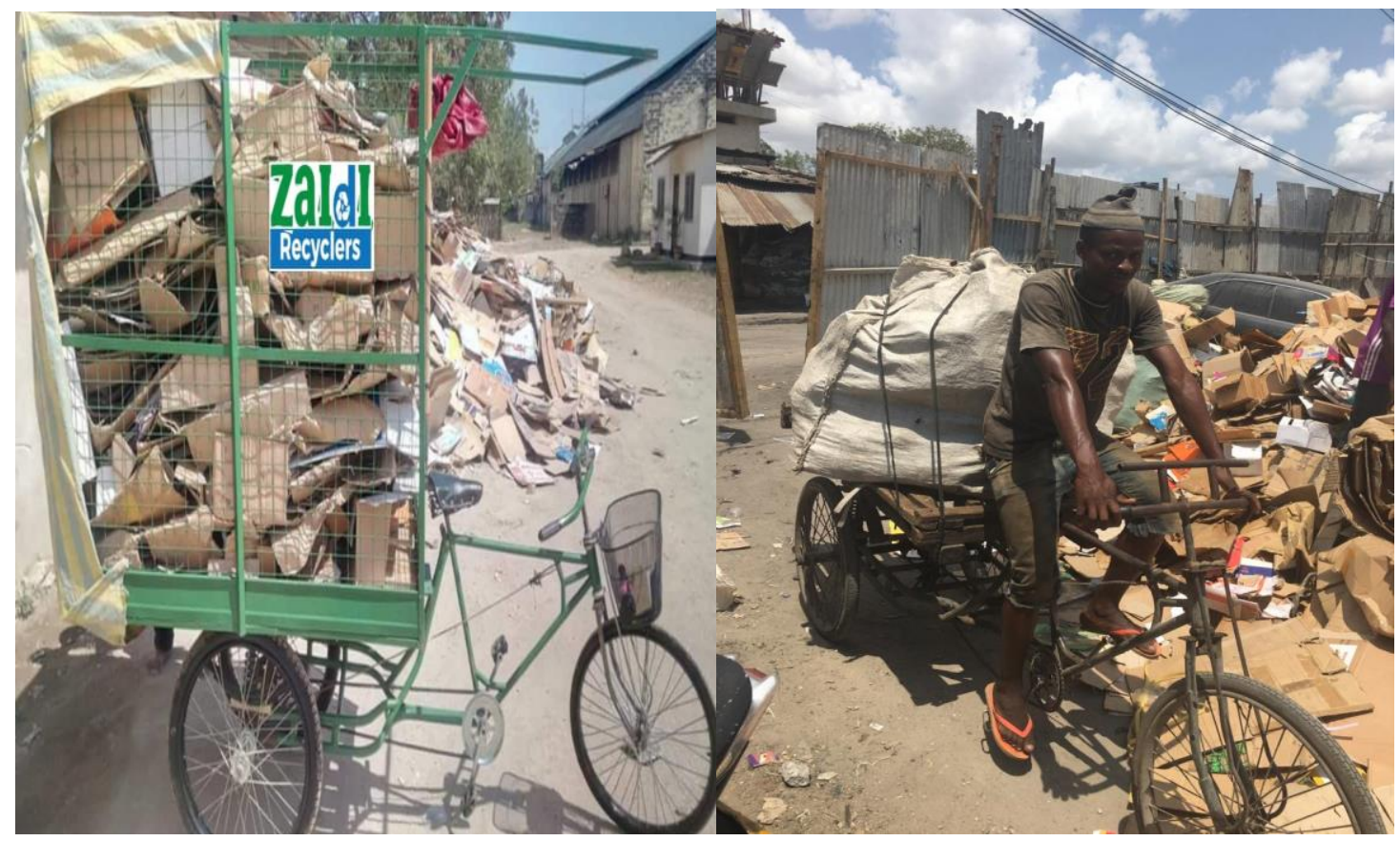

Fig 3:- Collected cardboards at Zaidi recyclers'site

\section{- Lack of reliable data on solid waste disposal}

The Ilala Municipal Council found to lack reliable data on the amount of waste disposed and where disposed by the informal waste collectors. However, the study found that Informal service providers dispose the collected waste in authorized areas such as rivers, valleys, open space and along the roads. Figure 4 shows informal service providers throwing waste at Msimbazi River in Vingunguti ward.

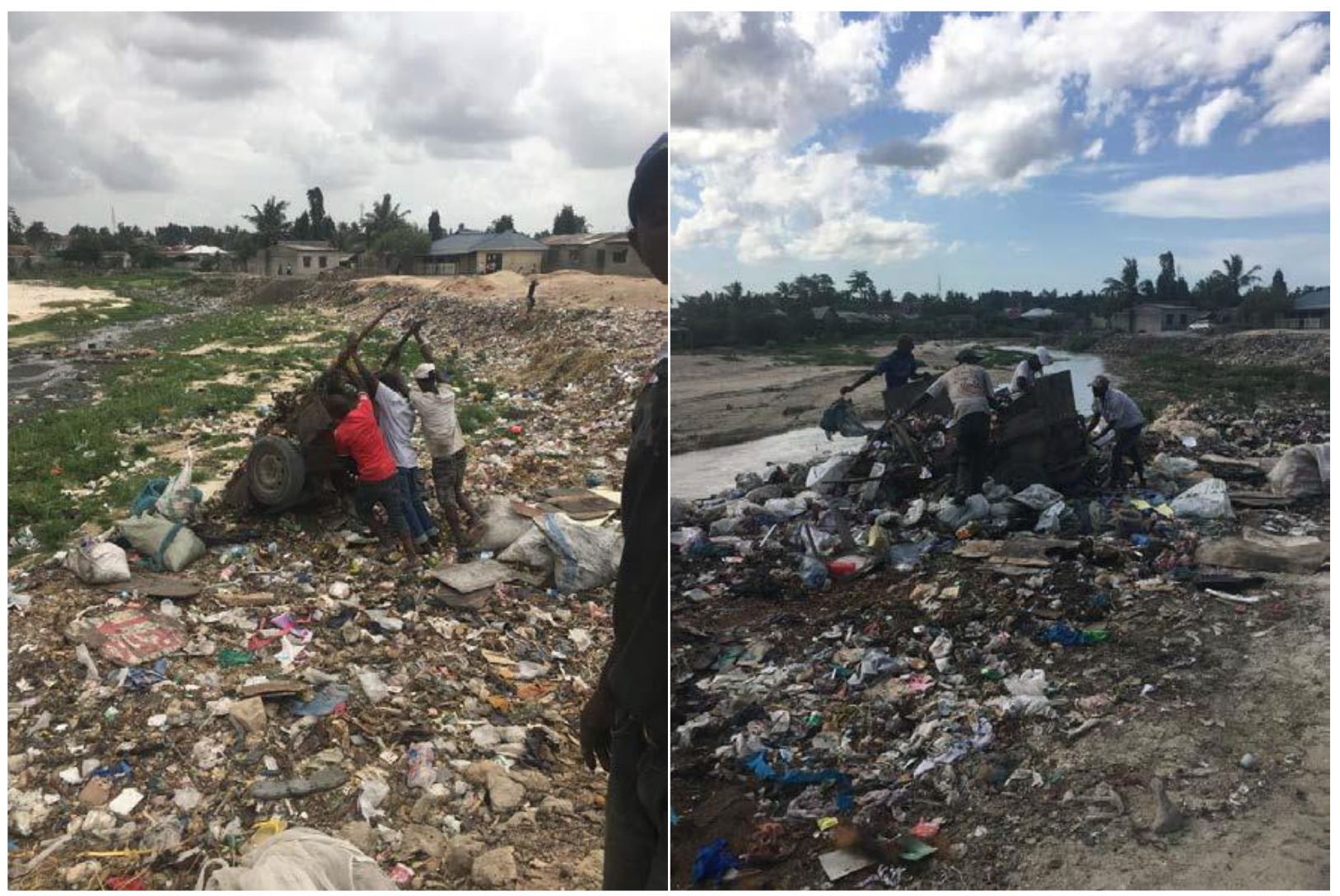

Fig 4:- Informal service providers dispose waste in Msimbazi River-Vingunguti ward Source, Hussein (2020). 


\section{$>$ Inadequate Convenient Payment Systems}

Both Municipal officers and 100 per cent of service providers' respondents have indicated that direct cash as the most common payment mode for Refuse Collection Charges in the Municipality. It was also, reported few incidences where customers pay through Bank checks. This found to apply mostly to institutions or businesses. The house to house refuse charges collection was observed to be commonly applied method. This reported and observed to be happening at the end of the month through physical house to house visitations.

However, lack of alternatives systems of payment such as mobile payment has affected the collection efficiency. It was observed and reported that it requires a physical contact to make payment. This affect the collection rate due to the fact that some service recipients normally come home late. Consequently, the RCCs collection rate found to be less than 50 percent for 66 percent of the total Wards in the Municipality.

\section{$>$ Inadequate Transparent Systems}

The Municipality observed to use Point of Sale Machines (POS) in the collection of RCCs. The POS machines enable the municipal council to trace only revenue collected by contracted waste collection companies who covers less than 40 per cent of the municipality. The CBOs and SMEs are providing waste collection services at a greater portion of the municipality without using POS machines. Lack of transparent systems denied the council not only revenue but the ability to assess the level of willingness of residents to pay for waste collection services. For example, MANDELA Cleaners Group served 1200 households in Bonyokwa and Kisiwani sub-wards. However, the RCCs payment from this Ward cannot be traced by municipal council.

Additionally, lack of comprehensive electronic customers' data base has made the use of POS machines ineffective in capturing all the collected RCCs. There were reported and observed incidences where RCCs collectors did not use POS machines while collecting the refuse charges. This has been made possible due to lack of effective customers' registration system which can enable municipal council and service providers to track the revenue against the number of registered service recipients.

\section{> Ineffective bill delivery systems}

According to Rao (2012) billing processes play a critical role in revenue collection for a number of public sector organisations including municipalities. Utility agencies such as Water supply and electricity supply companies have been using billing system as a way of reminding their customer to pay for the enjoyed services. This has been proven successful in the collection of user charges (Rao, 2012). However, in Ilala Municipality 100 percent of the service provider respondents were observed and reported of not issuing bills for the offered services. This denied them the required effectiveness in assessing payment response by services recipients over time. Service providers through RCCs collectors physically move from house to house for the collection of RCCs.

\section{$>$ Weak Enforcement}

According to UNEP (2015) the payment of fees or user charges has never been 100 percent. A good sustainable payment rate for Municipal solid waste management is considered to be around 90 percent (ibid). In Ilala Municipality the user fees collection rate found to be less than 50 percent for (24) Wards which is over 67 percent of the total Wards in the Municipality. However, the Central Business District which account for 33 percent of the total Wards in the municipality the user fees collection was found to have reached 80 to 90 percent. The practiced user fees collection system found to affect the enforcement process. The house to house user fees collection system observed to be affected by several issues including; unavailability of the customers during fees collection, lack of reliable service recipient data base, inadequate fees collection staffs, ineffectiveness and dishonesty of some user fees collectors. The common enforcement practice observed was the uses of municipal headquarter militia through the established mobile court and Ward tribunals. However, the council found to rely on the list of defaulters given by service providers which subjected to shortcomings such as inadequate staffs, lack of comprehensive service recipient data base and ineffectiveness and dishonesty of some user fees collectors. This reported to cause delays in the enforcement process

Additionally, according to UNEP (2015) the enforcement in the collection of refuse charges has been very effective when collected with other utility bills such as electricity, water or phone bills. Sanctions for defaulters through utility bills considered to be easy and more reliable as opposed to the house to house user fees collection system. However, this was not found to be practiced in Ilala Municipality.

\section{CONCLUSSION}

Lack of comprehensive data collection system has made the waste management data in the Municipality unreliable. Consequently, planning for waste management service provision and recovery of waste management cost through RCCs collection become ineffective. The RCCs collection system in the municipality characterized by manual based customers' registration system, inadequate transparent systems, limited convenience payment options and ineffective enforcement processes.

\section{RECOMMENDATIONS}

\section{$>$ Introduction of Electronic Customer Registration Systems \\ The Municipal council should ensure all properties in the Municipality are registered electronically. This can be done through assigning properties with tags or barcodes which provide the details of the service recipients including Global Positioning System (GPS) location and the expected RCCs amount to be paid at each property. This can be}


implemented by phase starting with Wards at the Central Business District. To easiest its execution this requirement can be introduced in the tendering process. The service providers may be given a condition of establishing electronic registration system in areas they are expected to service. However, this should be accompanied by provision of longer contracts of at least three years. The system should also, be linked with payment system where any effected payment can immediately be reflected in the system in real-time.
Improvement of Reliable Manually Waste Management Data Collection System

The solid waste management Regulations (2009) requires Local Government Authorities to conduct periodic waste management study among other things to determine the amount of waste generated, collected, and disposed. Inadequate resources may delay immediate establishment of the electronically customers' registration system. The Municipality should use the existing governance structure to generate data on the amount of waste generated daily/monthly and annually. Figure 4 shows the role that each level of governance can play to generate municipal own data.

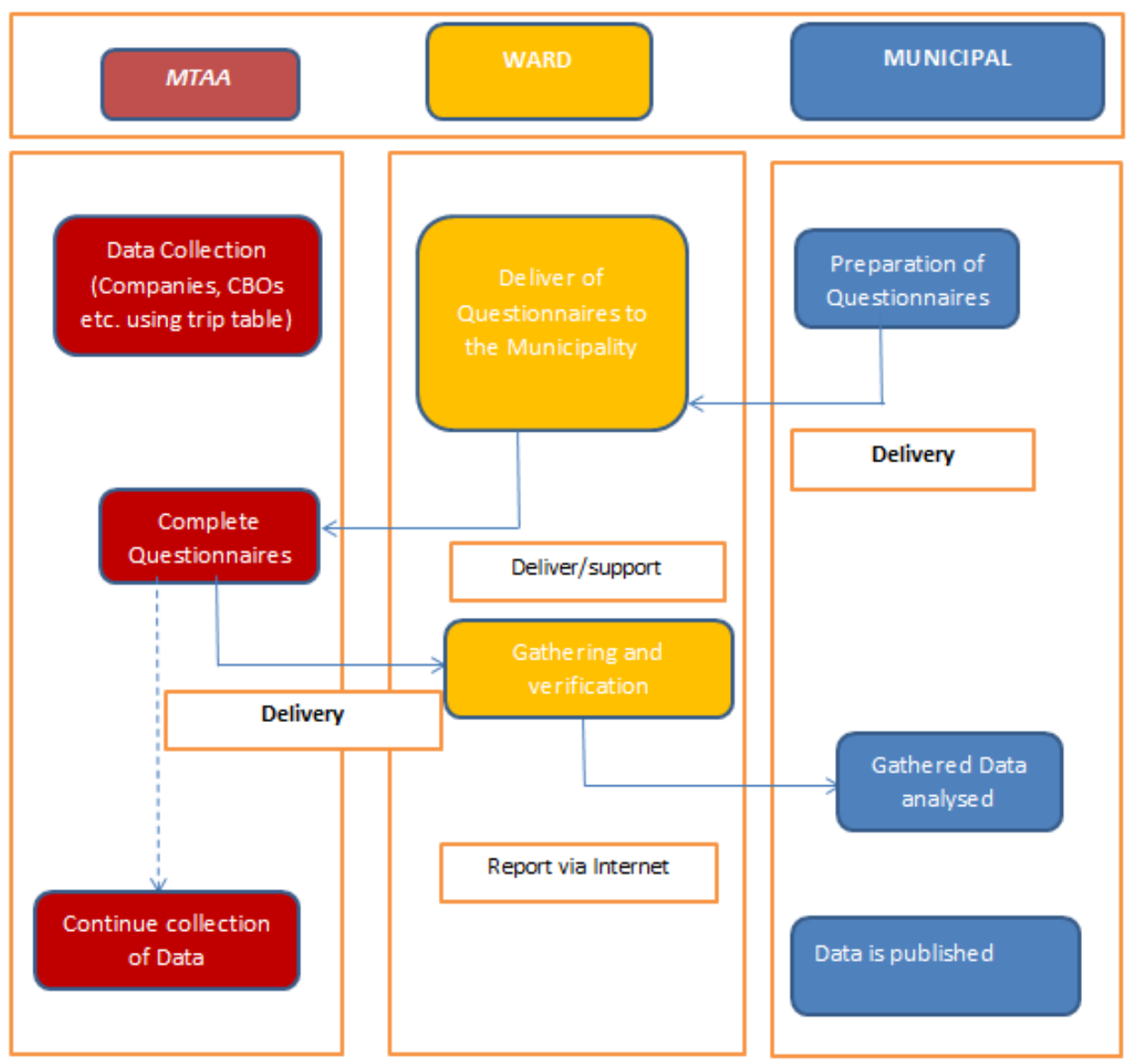

Fig 5:- The Actors Distribution Roles in the Development of Waste Management Data Base

\section{- The role Mtaa offices}

The Mtaa executive officer shall be the centre of data collection with regards to waste management. The office shall be responsible for keeping records of the equipment and trip made by each equipment in his/her area of jurisdiction. The Mtaa offices will have a Matrix that records the amount of waste collected by every service provider in his/her area of jurisdiction. Table 5 shows a matrix that can be used by Mtaa offices to record all collected in their areas of jurisdiction.

\begin{tabular}{|c|c|c|c|c|c|}
\hline Type of eqipment & ID & Description & Measures & Capacity & T/M3 \\
\hline $\begin{array}{c}\text { e.g. Compactor, } \\
\text { open tipper, TOYO } \\
\text { e.t.c. }\end{array}$ & $\begin{array}{c}\text { Truck } \\
\text { registration } \\
\text { number }\end{array}$ & E.g. Blue, Red & LxHxW & M3 & \\
\hline & & & & & \\
\hline
\end{tabular}

Table 5:- Waste Collection Estimate Matrix

NB: The data in cubic meter can be converted into tons through multiplication with 0.3 for flat beds trucks and by 0.5 for compactor truck. 
Additionally, Mtaa Executive Office will also, be responsible on filling questionnaires that might be developed by Municipal Headquarter to capture information on the number of households/houses served by the service provider. The questionnaires will be filled on daily basis and submitted on weekly basis to the Ward Executive Officer.

\section{- The role of Ward office}

The Ward executive officer will play an intermiadiate role between the Municipal headquarter and Mtaa offices. The office will receive data from the Mtaa executive offices and compile them. On Weekly basis the data will be submitted to the Municipal Headquarter through electronic systems such as email or any other developed systems to ensure the possibility of having a back ups in case of misplacement of data. Also, the Ward Executive office will be delivering questionnaires developed by Municipal headquarter to capture information on the number of households served on daily basis. The Ward exective officer will submit the filled questionnaires to the Municipal headquarter on a monthly basis.

\section{- The role of Municipal Council}

The municipal headquarter will aggregate the data for all Wards. The municipal headquarter will publish the data on annual basis. Also, the Municipality should develop questionnaires for capturing other data such as waste composition whener necessary. The questionnaires will be given to Ward Executive Officers . The Municipal headqurter will then receive the filled questionnaires on monthly basis for analysis to determine the service coverage and amount of waste generated. Finally the Council will publish the results.

\section{REFFERENCES}

[1]. Hussein M.O (2020). Implication of Refuse Collection Charges Practices on Waste Collection Services in Selected Areas in Tanzania. In the Global Scientific Journals. Vol.8/ Issue 3/March 2020, Online ISSN 2320-9186

[2]. Hussein, M. O., Kiwango, N. and Bullu, S., (2019). Potential and Challenges of Informal Solid Waste Collection Services: The Case of Sandali Ward, in Temeke Municipality. Global Scientific Journal. Vol. 7, Issue 11, November 2019. Online. ISSN 2320-9186

[3]. Kingu, A., and Yhdego, (2016).Solid Waste Management in Urban Centres of Tanzania Leapfroging towards a Circular Economy.

[4]. Rao, S. (2012). Helpdesk Research Report: Impact of municipal billing systems on revenue collection. Governance and Social Development Resource Centre.

[5]. Spaargaren, Gert, Peter Oosterveer, Joost van Buuren, and Arthur P.J Mol (2005). Mixed Modernities: towards viable urban environmental infrastructure development in East Africa. 1 Position paper. Environmental Policy Group, Wageningen University and Research Centre, The Netherlands.
[6]. United Nation Environment Programme (2016). Global Waste Management Outlook, UN, New York, https://doi.org/10.18356/765baec0-en.

[7]. United Republic of Tanzania (1982).Local Government Authority Act (1982).

[8]. United Republic of Tanzania (2018). Dar es Salaam Master Plan 2016-2036

[9]. 